\title{
A Study on Attitudinal Meanings of Different Narrative Roles in Emma
}

\author{
Sihui Liu \\ Department of Foreign Languages, Guangdong Polytechnic College, Zhaoqing, China
}

\begin{abstract}
By adopting the Attitude System within the Appraisal System and the concepts of narrative roles and narrative points of view within narratology as the theoretical framework, the present study aims to analyze the distribution of attitudinal meanings, find out the similarities and differences of attitudinal meanings expressed by different narrative roles from different points of view and discuss how attitudinal meanings contribute to the analysis of the character depiction, plot development, theme presentation and the expression of irony in Emma.
\end{abstract}

Index Terms — appraisal System, attitudinal meaning, narrative roles, Emma

\section{INTRODUCTION}

Jane Austen, as one of the most famous and popular masters of the English novels, is good at employing irony to depict the characters of her time especially middle-class ladies and explore their social and moral problems they have been faced with. Her masterpiece Emma tells a story about a wealthy lady called Emma who is full of enthusiasm about matchmaking her friends instead of thinking about her own marriage. Up to now, many scholars have researched the novel from different perspectives such as feminism, archetypal criticism and comparative literature. However, few of them explore it from the perspective of attitudinal meanings within the framework of the Appraisal System.

The Appraisal System, is a development of the interpersonal function in Halliday's Systemic-Functional linguistics. In 1990s, James Martin extended the study scope of interpersonal function and proposed the Appraisal System. The system consists of three subcategories, namely Attitude, Engagement and Graduation. Since the first introduction of the Appraisal System, it has been attracting many scholars to conduct researches on it. The first application of the theory is an analysis of the attitudinal system in journals. Then the system is applied to many other fields such as discourse analysis, literature, translation, cognition and so on, but inscribed and invoked attitude are hardly discussed in light of narrative roles and narrative point of view in narratology.

Therefore, the thesis adopts the Appraisal System and narratology as the theoretical framework and aims to study the ways of character depiction, plot construction, theme presenting and the expression of irony in the novel Emma by analyzing the attitudinal meanings of different narrative roles.

\section{LITERATURE REVIEW}

\section{A. The Appraisal System}

Martin and White (2005) proposed that evaluation itself consists of three interacting domains which are Attitude, Engagement and Graduation. Martin and White (2005) also pointed out that interpersonal meaning is based on the lexical level and evaluative meaning is on the lexicogrammatical level through the realization of evaluative lexis.

Although the Appraisal System has not become a systematic and comprehensive theory until 2005, a number of scholars abroad have discussed its applications especially in discourse analysis since 1990s. The study of media discourses first drew attention among scholars. Iedema, Feez and White (1994) studied evaluations in journalistic discourses featured in their objectivity and subjectivity, their evaluative values, their relationships and changes of voices. White (2001) made a further analysis of semantics about attitude, evaluation and intersubjectivity through a study of different kinds of news reports. Furthermore, narrative discourses are widely studied under the framework of the Appraisal System. Martin and Plum (1997) endeavored to prove that it is significant to deploy evaluations to analyze the interaction of events in narrative. Macken-Horarik (2003) intended to investigate how the Appraisal System is applied to analyze the relations between the writer and the readers in narrative discourses. Page (2003) analyzed the evaluation expressed by women and men when narrating some experiences about childbirth.

\section{B. Narrative Roles}

The earliest studies on the narrative communication can date back to an analysis of Language Communication Mode by Jakobson (1960), who proposed six factors of verbal communication, namely the addresser, the addressee, message, code, context, and contact. American narratologist Chatman (1978) also proposed a well recognized narrative communication mode by many narratologists, as an attempt to illustrate both film narrative and text narrative. Rimmon-Kenan (2002) held an opposite opinion that the narrator and narratee are optional. Toolan (1988) believed that 
the narrative communication made by Manfred is too complex, so he proposed an easier mode in which he omitted the implied author and the implied writer. Chinese scholar Shen (2010) pointed out the narrative transaction should be canceled. Obviously, Shen gave a high affirmation to the narrative communication proposed by Chatman. Peng (2015) cited Chatman's narrative communication mode and studied the evaluative meanings and their relations with different narrative roles as appraisers. By adopting the Figure-Ground Theory and the narrative communication mode as theoretical framework, he analyzes three kinds of narrative roles who can express attitudinal meanings, namely the narrator, the character and the implied author. Peng uses a systematic network to make a conclusion about the phenomenon that the thesis has discussed. Firstly, the network with different allocation modes exposes the evaluative stances of different levels and categories, which indicates the multiplicity and complexity of the evaluative meanings. Secondly, in theory, the network can be used to deal with all kinds of resource allocations, which means each mode may consist of more than two kinds of narrative roles. Thirdly, these different allocation modes may be included in the same text. Therefore, the research not only provides an effective theoretical framework for evaluative values of stylistics, but also a valid way for the identification of evaluative meaning in discourses. It is a refinement of the Appraisal System itself as well. Fourthly, according to the former analysis, it can be seen that the evaluative stance of the implied author can be implied by the character.

\section{ATTITUDE SYSTEM}

Attitude mainly refers to those values by which speakers attach evaluations to participants and processes by reference either to emotional responses or to systems of culturally-determined value systems (White, 2001). Attitude is construed by feelings, including Affect, Judgement and Appreciation. The system consists of three semantic regions covering what is traditionally referred to as emotion, ethics and aesthetics respectively. "Affect is concerned with construing positive and negative feelings: do we feel happy or sad, confident or anxious, interested or bored?" (Martin \& White, 2008:42). Judgement is used for evaluating whether human's actions and dispositions are fine or not in light of some regulatory rules. It is the evaluation of human's behavior, which we admire or criticize, praise or condemn. It can be sub-divided into social esteem and social sanction. Appreciation has three sub-categories which are reaction (impact and quality), composition (balance and complexity), and valuation (how innovative, authentic, timely, etc.). The core of the Appraisal System is Attitude, which can be construed by inscribed Attitude and invoked Attitude.

\section{Distribution OF ATtitude}

Attitude is concerned with speaker's feelings, including emotional reactions, judgement of human's behavior and evaluation of things and we can locate appraisal as an interpersonal system at the level of discourse semantics. Due to limited space and time, 45 selected texts in volume 1 of Emma are analyzed and discussed in this thesis. And both of them contain 15 texts with double appraisal stance allocation, 15 triple appraisal stance allocation and 15 quadruple appraisal stance allocation respectively.

TABLE 1

DISTRIBUTION OF ATTITUDE RESOURCES DEPLOYED By NARRATIVE ROLES

\begin{tabular}{|l|l|l|l|l|}
\hline attitude Narrative roles & narrator & implied author & character & amount \\
\hline inscribed attitude & 197 & 49 & 170 & 416 \\
\hline
\end{tabular}

The above table shows there are altogether 416 attitude resources in volume 1 of Emma, in which 197 items are deployed by the narrator, 49 by the implied author and 170 items by the characters. The reason why there are more inscribed attitude resources deployed by the narrator and the character is that in volume 1 of Emma, the first three chapters are mainly narrated from the omniscient point of view, which means from the narrator's point of view. The first three chapters are some basic introductions of the background of the novel and an introduction of the main character Emma such as Emma's reaction when she knows Miss Taylor will get married. Then from the beginning of the fourth chapter, some other main characters are narrated from character's point of view, such as Mr. Woodhouse, Mr. Knightley. So when more characters appear in a novel, it is unavoidable that many more conversations are generated, and then more attitude resources are used by the characters. However, the implied author is always hidden in a novel so that it covers fewer frequencies compared with attitude resources by the narrator and the characters.

\section{A. Distribution of Affect Resources}

The distribution of affect resources is as follows: 
TABLE 2

DISTRIBUTION OF INSCRIBED AFFECT RESOURCES

\begin{tabular}{|c|c|c|c|c|c|}
\hline \multicolumn{2}{|c|}{$\begin{array}{ll}\text { inscribed affect } & \text { narrative roles } \\
\end{array}$} & narrator & implied author & character & amount \\
\hline \multirow[t]{2}{*}{ dis/inclination } & positive & 10 & 2 & 7 & 19 \\
\hline & negative & 2 & 1 & 3 & 6 \\
\hline \multirow[t]{2}{*}{ un/happiness } & positive & 10 & 2 & 8 & 20 \\
\hline & negative & 4 & 0 & 3 & 7 \\
\hline \multirow[t]{2}{*}{ in/security } & positive & 11 & 4 & 9 & 24 \\
\hline & negative & 2 & 0 & 0 & 2 \\
\hline \multirow[t]{2}{*}{ dis/satisfaction } & positive & 10 & 2 & 5 & 17 \\
\hline & negative & 0 & 1 & 3 & 4 \\
\hline \multicolumn{2}{|l|}{ amount } & 49 & 12 & 38 & 99 \\
\hline
\end{tabular}

It shows that affect resources of the narrator (49 times) and the character (38 times) are more than those of the implied author (12 times), which indicates the narrator and the character always express their attitude in Emma in a more direct and frequent way than the implied author. And in each subcategory, the positive affect resources are more than the negative ones. In the former chapters, the narrator uses many positive words to describe Emma and the character Emma also gives high evaluations to Harriet. In the following chapters, Mr. Knightley uses some positive affect words to show his high evaluations to Emma. And some negative affect words are used in the descriptions about Emma and Mr. Woodhouse's sad feelings of Taylor's marriage.

\section{B. Distribution of Judgement Resources}

The distribution of judgement resources is shown in the following table:

TABLE 3

DISTRIBUTION OF JUDGEMENT RESOURCES

\begin{tabular}{|l|l|l|l|l|l|}
\hline \multirow{2}{*}{ inscribed judgement } & narrative roles & narrator & implied author & character & amount \\
\hline \multirow{2}{*}{$\begin{array}{l}\text { social esteem } \\
\text { (normality) }\end{array}$} & positive & 10 & 3 & 8 & 21 \\
\cline { 2 - 6 } & negative & 2 & 6 & 3 & 11 \\
\hline \multirow{2}{*}{$\begin{array}{l}\text { social esteem } \\
\text { capacity) }\end{array}$} & positive & 5 & 2 & 6 & 13 \\
\cline { 2 - 6 } & negative & 12 & 4 & 11 & 27 \\
\hline \multirow{2}{*}{$\begin{array}{l}\text { social esteem } \\
\text { (tenacity) }\end{array}$} & positive & 18 & 3 & 31 & 52 \\
\hline \multirow{2}{*}{$\begin{array}{l}\text { social sanction } \\
\text { (veracity) }\end{array}$} & negative & 10 & 4 & 3 & 17 \\
\hline \multirow{2}{*}{$\begin{array}{l}\text { social sanction } \\
\text { propriety) }\end{array}$} & positive & 9 & 2 & 6 & 17 \\
\hline megative & 8 & 3 & 4 & 15 \\
\cline { 2 - 6 } & positive & 15 & 3 & 11 & 29 \\
\hline
\end{tabular}

The table indicates that judgement resources used by three appraisers are 102, 35 and 93 items respectively, which cover a relatively high amount compared with affect resources and appreciation ones. This is because characters are the most important components in a novel and the depictions of characters must be realized by their behaviors and conversations. In addition, the amount of positive judgement resources surpasses those of negative ones. In addition, the positive evaluations of the narrator $(57>45)$ and the character $(62>31)$ are both more than the negative ones. On the contrary, the positive judgement resources by the implied author $(13<22)$ are less than the negative ones. It can also be seen that in a text, there is not only one appraiser and there can be two or more than two appraisers. More importantly, the frequencies of the negative evaluations of the implied author are more than that of the positive ones by the narrator and the character, which is the reason why the novel is full of rhetorical devices of irony.

\section{Distribution of Appreciation Resources}

The following table shows the distribution of appreciation resources:

TABLE 4

DISTRIBUTION OF APPRECIATION RESOURCES

\begin{tabular}{|l|l|l|l|l|l|}
\hline \multirow{2}{*}{ roles appreciation } & Narrative & narrator & implied author & character & amount \\
\hline \multirow{2}{*}{ reaction } & positive & 26 & 1 & 26 & 53 \\
\cline { 2 - 6 } & negative & 4 & 0 & 2 & 6 \\
\hline \multirow{2}{*}{ composition } & positive & 7 & 0 & 8 & 15 \\
\cline { 2 - 6 } & negative & 0 & 0 & 0 & 0 \\
\hline \multirow{2}{*}{ valuation } & positive & 8 & 1 & 2 & 11 \\
\cline { 2 - 7 } & negative & 1 & 0 & 39 & 87 \\
\hline amount & 46 & 2 & & 2 \\
\hline
\end{tabular}

According to the above table, appreciation resources used by the narrator $(46>2)$ and character $(39>2)$ cover more frequencies than those by the implied author. This is because the narrator's narration covers most parts in the first three 
chapters and the character's narration in the next following chapters. Shown in Table 4-5, positive reaction resources are used most frequently among appreciation resources, because characters always describe something by appreciation evaluations. For example, the narrator describes that Emma "units some best blessings of existence".

The table reflects that the distribution of these three appraisers is different, but reaction resources inscribed by the narrator, the character and the implied author are more than composition and valuation, whose reason is that reaction can deliver characters' feelings in a better way. Hence, these three appraisers focus more of their evaluations on reaction than on composition and valuation.

In conclusion, it should be noticed that when narrative roles hold the congruent inscribed attitude, they expose the similar characterization, plot and theme. However, when narrative roles hold the incongruent attitude, it may invoke other attitudinal subcategories and they aim to reveal a sarcastic tone in the text.

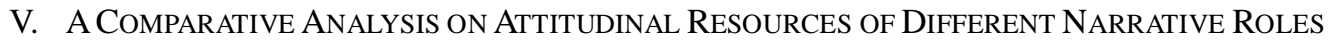

\section{A. A Comparative Analysis on Attitudinal Meanings of the Narrator and the Implied Author}

According to Chatman's flow chart of narrative exchange mode (1978), the narrator is a sender of narrative information and the implied author is the image of the writer produced by readers. Hence, when a text is narrated by the narrator, the implied author also narrates although their evaluative stances may be congruent or incongruent. Moreover, in the first three chapters in Emma, most are narrated by the narrator from the omniscient point of view and some basic background information is introduced. Then in the next following chapters the omniscient point of view is transferred to selective omniscient point of view that only shows the main character Emma's inner activities to readers and fixed internal point of view which shows other characters' inner activities.

a. The congruent attitudinal stance

(1) She was the youngest $(+5)$ of the two daughters of a most affectionate $(+2)$, indulgent $(+2)$ father; and had, in consequence of her sister's marriage, been mistress of his house from a very early period. Her mother had died too long ago for her to have more than an indistinct (-11) remembrance of her caresses; and her place had been supplied by excellent woman as governess, who had fallen little short of a mother in affection.

At the beginning of the novel, Emma is described from the omniscient point of view. She is "young" $(+5)$ and is "affected" $(+2)$ and "indulged" $(+2)$ by his father. And she has an "indistinct" $(-11)$ remembrance of her mother. In this text, the narrator holds the congruent opinion with the implied author that Emma, as the young hostess of her house, can do anything that she likes under the protection of her father. Therefore, at the start of the novel, the description of Emma by the narrator gives a first impression on her and intrigues readers' interest, which leads readers to think what will happen to Emma with those dispositions.

b. The incongruent attitudinal stance

(2) She recalled her past kindness $(+8)$ - the kindness $(+8)$, the affection $(+2)$ of sixteen years - how she had taught and how she had played with her from five years old-how she had devoted all her powers to attach $(+3)$ and amuse $(+3)$ her in health - and how nursed her through the various illnesses of childhood. A large debt of gratitude $(+3)$ was owing here;

The pattern of attitudinal meanings is shown by the figure:

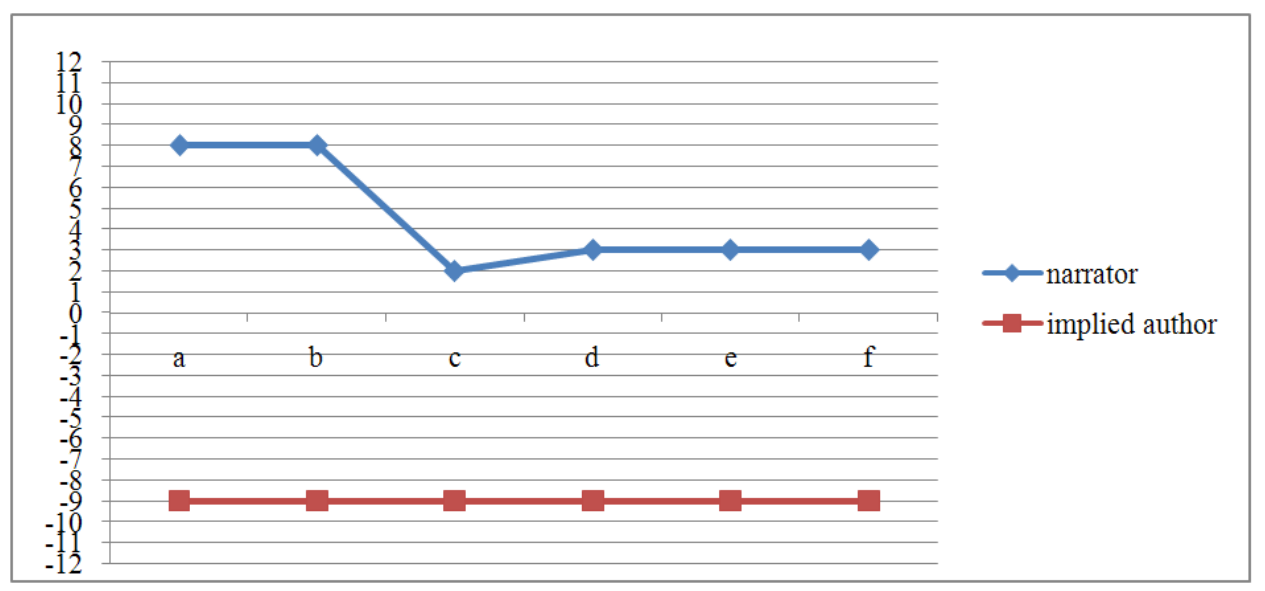

Figure 1 The Pattern of Attitudinal Meaning In Example 2

At the beginning of this selected text, the verb "recall" is a mental process which can reflect that the following text is what Emma is thinking about. The selected omniscient narrator Emma describes Taylor with such words as "kindness" $(+8)$ and "affection" $(+2)$. The narrator uses "attach" $(+3)$ and "amuse" $(+3)$ to recall the time when Taylor is not married and Emma has a kind of "gratitude" $(+3)$ to Taylor. When reading this part, readers sympathies and feels pity because Emma loses her close friend. But through the following narration, Emma feels happy again when she finds she 
can have matchmaking with Harriet. It can be seen that the selected discourse is a negative propriety (-9) evaluation presented by the implied author. Thus, this paragraph not only lays a foundation of revealing Emma's real deposition in the following chapters, but also promotes the development of the plot. And in this text, the story is almost narrated from Emma's point of view which is a selected omniscient point of view. Emma shares her thoughts even her mistakes with readers. In this novel, most narrations are used from Emma's perspective. For example, when Emma has some conflicts with other characters, the narrator will narrate through Emma's point of view so that readers may think about the situation in Emma's place and their stance will be quite influenced.

\section{B. A Comparative Analysis on Attitudinal Meanings of the Narrator, the Character and the Implied Author}

a. The congruent attitudinal stance

(3) "Emma knows I never flatter (+7) her," said Mr. Knightley, "but I meant no reflection (+5)on anybody. Miss Taylor has been used to have two persons to please $(+3)$; she will $(+1)$ now have but one. The chances are that she must (+7) be a gainer."

In chapter one, Knightley talks about Taylor's marriage with Emma and Mr. Woodhouse. Through his words Emma knows he "never flatters" (+7) her, it seems that Emma has a close relationship with Mr. Knightley. And the expression "no reflection on anybody" belongs to the subcategory of normality (+7), which demonstrates Mr. Knightley is righteous (+9). At last Mr. Knightley uses such words as "please" $(+3)$, "will” $(+1)$ and "must" $(+7)$ to evaluate Taylor's decision. The use of these three words shows that Mr. Knightley is upright (+9) and outspoken (+9). In Emma, Knightley always expresses his opinion in a direct way such as his dissatisfaction to Harriet's refusal to the proposal by Martin. Hence, the implied author and the narrator hold the same opinion that Knightley is righteous (+9).

b. The incongruent attitudinal stance

(4) "Exactly so; that is what principally $(+11)$ strikes me. So much superadded (+9) decision of character! Skilful (+6) has been the hand!"

(5) "Exactly so - The shape of the eye and the lines about the mouth - I have not a doubt (+7) of your success. Pray, pray attempt it. As you will do it, it will indeed, to use your own words be an exquisite $(+10)$ possession."

These two paragraphs are listed in the same pattern:

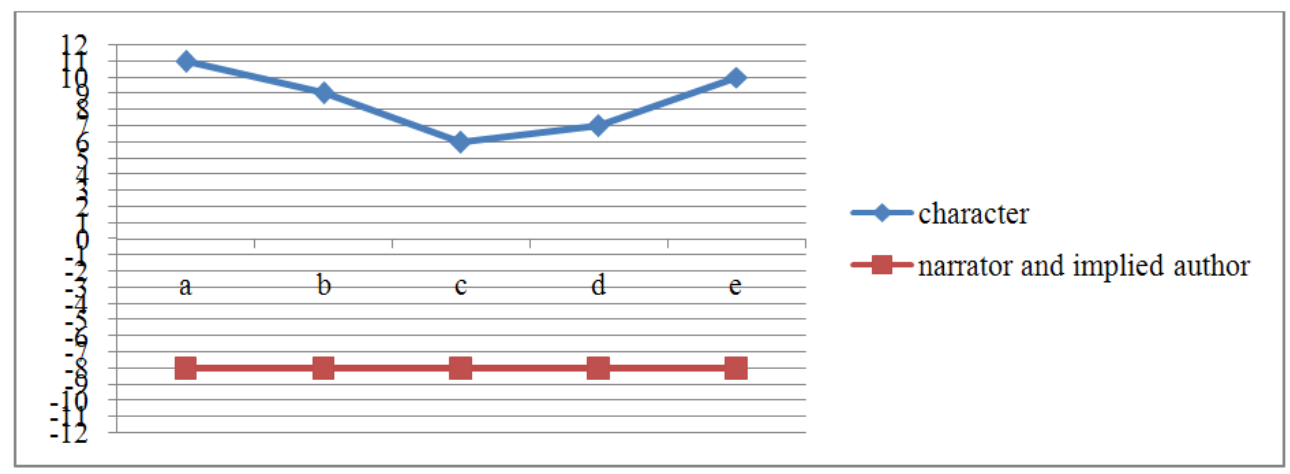

Figure 2 The Pattern of Attitudinal Meaning in Example 4-5

These two examples are selected from the sixth chapter. The first example occurs when Elton agrees with Emma's words on her "giving Harriet more decision". Elton adopts "superadded" (+9) and "skilful" (+6) to praise Emma. The attitudes he adopts are propriety and capacity resource. In essence, although the character Elton gives high praise on Emma, the narrator and the implied author hold the opposite opinion. Because after the picture is painted by Emma, Knightley thinks that Emma paints Harriet too tall and Emma also knows what she has done. Here, the narrator and the implied author have a mockery to Elton's hypocrisy $(-8)$.

\section{A Comparative Analysis on Attitudinal Meanings of the Narrator, the Implied Author, Character1 and Character2}

a. The congruent attitudinal stance

(6) "I have always thought it a very foolish intimacy (-10)," said Mr. Knightley presently, "though I have kept my thoughts to myself; but I now perceive that it will be a very unfortunate (-10) one for Harriet. You will puff her up (-12) with such ideas of her own beauty, and of what she has a claim to, that, in a little while, nobody within her reach will be good (+10) enough for her. Vanity (-8) working on a weak head, produces every sort of mischief. Nothing so easy as for a young lady to raise her expectations too high. Miss Harriet Smith may not find offers of marriage flow in so fast (+9), though she is a very pretty $(+10)$ girl. Men of sense, whatever you may chuse to say, do not want (-1) silly wives (-6)."

The conversation talks about Knightley's idea about the relationship between Emma and Harriet. Mr. Knightley deploys many negative evaluative lexis to show that it is such a dangerous thing that Harriet makes friends with Emma. Although Mr. Knightley is one of the main characters in Emma, he is like a narrator to visualize everything around him. This is why we say Knightley is an agent of the implied author.In the novel, Knightley thinks Emma and Harriet have a foolish intimacy and it will be an unfortunate thing for Harriet to make "friends" with Emma. This is also the opinion that the narrator and the implied author intend to express. 


\section{The Incongruent Attitudinal Stance}

(7) "Oh no, no! The letter had much better $(+7)$ be all your own. You will express yourself very properly $(+9)$, I am sure. There is no danger of your not being intelligible, which is the first thing. Your meaning must (+7) be unequivocal"

(8) "Ought to $(+7)$ refuse him! My dear Harriet, what do you mean?"

(9) "I shall not $(+7)$ give you any advice, Harriet."

(10) "I lay it down as a general rule, Harriet, that if a woman doubts as to whether she should accept a man or not, she certainly ought to $(+7)$ refuse him."

(11) "Not for the world," said Emma, smiling graciously, "would $(+7)$ I advise you either way. You must $(+7)$ be the best $(+10)$ judge of your own happiness $(+2) . "$

(12) "Perfectly, perfectly right $(+10)$, my dearest Harriet."

(13) "He must $(+7)$ have a pretty good opinion of himself."

(14) Emma assured $(+8)$ her there would be no difficulty $(+11)$ in the answer, and advised its being written directly, which was agreed to, in the hope of her assistance;

The following figure shows the pattern of attitudinal meanings about Emma's words:

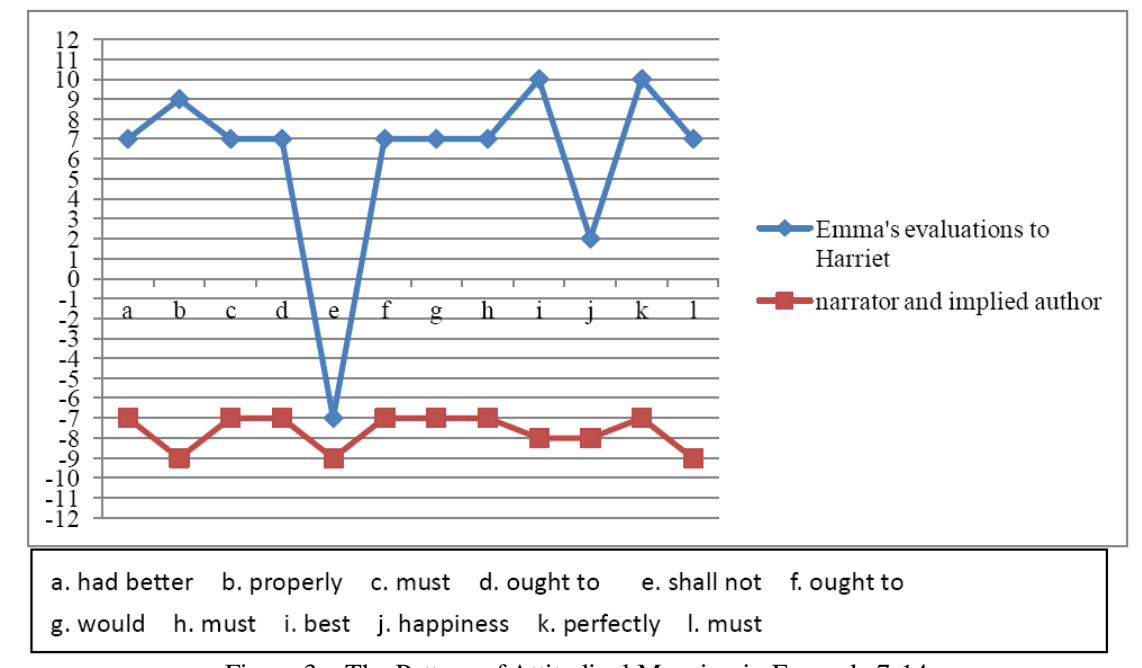

Figure 3 The Pattern of Attitudinal Meaning in Example 7-14

These conversations appear at the moment when Harriet seeks Emma's advice about whether she should marry Martin or not. In the beginning, Emma always says she shall not give Harriet any advice. We may feel that Emma respects Harriet and she doesn't interfere with her choice. However, in the following part, she chooses the positive capacity (+7) "must", "ought to" and "had better" to help Harriet make decisions. It reveals her strong desire of control $(-7)$ that Harriet requires her refusal of Martin's proposal. Then in the sentence "You must be the best $(+10)$ judge of your own happiness $(+2)$ ". It seems that Emma thinks that Harriet's decision is concerned with her future happy $(+2)$ life and Harriet should have a best $(+10)$ judgement. But in fact, Emma doesn't care about what Harriet's future life will become of and she only wants to make demand of her desire of control (-7), which demonstrates Emma's dishonesty (-9). As a matter of fact, she has already helped Harriet to make a decision. The implied author and the narrator demonstrate that Emma acts arbitrarily (-9).

As an agent of the narrator and the implied author, the character Knightley's inscribed evaluation can be equal to the views of the narrator and the implied author. According to Knightley's words, readers understand the temperaments of Martin and Harriet and the danger that Harriet makes friends with Emma more objectively and more clearly. Furthermore, when the character Emma evaluates Harriet, it seems that Emma cares about Harriet very much. In essence, it is an irony about Emma's strong desire of control (-7) implied by the narrator and the implied author. Thus, the congruence and the incongruence of the evaluations, generated by the character, and the narrator or the implied author, demonstrate the depiction of characters. More importantly, the incongruence is the essential condition under which a novel uses irony.

\section{CONCLUSION}

In light of the Attitude System within the Appraisal System and the concepts of narrative roles and narrative point of view within narratology, the thesis aims to discuss how the expression of attitudinal meanings of different narrative roles functions in the study of character depiction, plot development, theme presenting and the use of irony. Firstly, the sub-categories of inscribed and invoked attitude deployed by different narrative roles that appear in 90 selected texts in volume one of Emma are marked by their serial numbers within the framework of the Appraisal System. Then the distribution and realization of inscribed and invoked attitudinal meanings by narrative roles are given through a classification and statistical analysis of 90 selected texts with appraisal markers. Lastly, a comparative analysis of 
attitudinal resources of different narrative roles is made.

Through the analysis of volume one of Emma, major findings are as follows.

(1) The expressions of inscribed and invoked attitudinal meanings are related to narrative roles. The narrator and character's attitudes are usually expressed in the inscribed way and those of implied author are invoked.

(2) Different allocation modes are used in the novel. They are used in a prosodic way to realize the extension of the evaluations in order to transfer values of the author. In the double allocation mode, the stance of the implied author may be congruent or incongruent with the narrator. So it requires readers' profound understanding of the context, the background and so on. In the triple and quadruple allocation mode, the stance of the implied author is always reflected through views of the characters', especially those indirect descriptions violating ethics and morality.

(3) Different narrative roles as appraisers express different attitudinal meanings which may be congruent or incongruent with each other. When these appraisers hold the same stance, their attitudes contribute to the character depiction, plot development and theme presenting together. However, when the appraisers hold the opposite opinions, the implied author aims at expressing his ironic tone in the novel.

(4) The analysis of narrative point of view provides an objective basis for the identification of different appraisers, thereby helping to figure out the configuration of allocations of attitudinal meanings by different appraisers.

\section{REFERENCES}

[1] Chatman, S. (1978). Story and Discourse: Narrative Structure in Fiction and Film. New York: Cornell University Press.

[2] Iedema, R., Feez, S. \& White, P.R.R. (1994). Media Literacy (Write it Right Literacy in Industry Research Project Stage Z). Sydney: Metropolitan East Disadvantaged Schools Program.

[3] Jakobson, R. (1960). Closing Statement: Linguistics and Poetics. Style in Laguage, 1, 53-56.

[4] Macken-Horarik. (2003). Appraisal and the Special Instructiveness of Narrative. Tex, 23, 285-312.

[5] Martin, J. R., Plum, G. (1997). Construing Experience: Some Story Genres. Journal of Narrative and Life History, 7, 299-308.

[6] Martin J. R., White, P.R.R. (2005). The Language of Evaluation: Appraisal in English. London \& New York: Palgrave Macmillian.

[7] Page, R. E. (2003). An Analysis of Appraisal in Childbirth Narratives with Special Consideration of Gender and Storytelling Style. Text-Interdisciplinary Journal for the Study of Discourse, 23, 211-237.

[8] Peng Xuanwei. (2015). Appraisal Stylistics. Peking: Peking University Press.

[9] Rimmon-Kenan, S. (2002). The Story of "I": Illness and Narrative Identity. Narrative, 10, 9-27.

[10] Shen Dan, Wang Liya. (2010). Western Narratology: Classical and Postclassical. Peking: Peking University Press.

[11] Toolan, M.J. (1988). Narrative: A Critical Linguistic Introduction. London \& New York: Routledge.

Sihui Liu was born in Qitaihe, China in 1994. She received her M.A. Degree in English Language and Literature from Northeast Forestry University. She is currently an English Teacher in Guangdong Polytechnic College. 